\title{
Students' Perception of English Pronunciation Application in Pronouncing Ending -s
}

\author{
Vina Fathira ${ }^{1]}$, Diana Zuriati ${ }^{2]}$ \\ Sekolah Tinggi Bahasa Asing (STBA) Persada Bunda \\ E-mail: ${ }^{1]}$ vinafathira@gmail.com \\ ${ }^{2]}$ diana.zuriati77@gmail.com
}

\begin{abstract}
Using English Pronunciation in understanding ending $-\mathrm{s}$ is one technique to increase the students' competence, focusing in pronunciation, like in pronouncing ending $-\mathrm{s}$. In digital era, using English Pronunciation in understanding ending $-\mathrm{s}$ is the common technique since the students are actively getting involved in gadget. The researchers need in evaluating students' perception on using English Pronunciation in understanding pronunciation of ending $-\mathrm{s}$. The aim of this research is to investigate students' perception about the use of English Pronunciation in understanding ending -s. The method employed in this research was qualitative, and it was explained descriptively. The third year semester students at STBA Persada Bunda that used this English Pronunciation application in understanding ending $-\mathrm{S}$ were the population as well as the sample of this research. There were 10 students of STBA Persada Bunda in academic year 2018/2019 involved in this study. To collect the data, all students were asked before using English Pronunciation in understanding ending $-\mathrm{s}$ from online application and offline one. Then, the researchers distributed six questions related to the students' perception of using English Pronunciation in understanding ending $-\mathrm{s}$ by using interview with semi structured model. The result showed that, most of the third year students were pushed to use English Pronunciation in understanding ending $-\mathrm{s}$ in obtaining knowledge and joyful while learning process about voiced sounds, voiceless sound, and sibilant sound. In conclusion, the research about students perception is positive response by using English Pronunciation of pronouncing ending $-\mathrm{s}$.
\end{abstract}

Keywords: Students ' perception, English Pronunciation android application, pronouncing ending $-s$

\section{Persepsi Mahasiswa dalam Menggunakan English Pronunciation dalam Pengucapan Akhiran $-s$}

\begin{abstract}
Abstrak
Penggunaan English Pronunciation dalam memahami pengucapan berakhiran s (ending s) merupakan salah satu teknik untuk meningkatkan kompetensi siswa, berfokus pada pengucapan, seperti dalam pengucapan ending $-s$. Di era digital, penggunaan English Pronunciation dalam memahami akhiran -s merupakan teknik yang umum dilakukan karena siswa aktif terlibat dalam gadget. Peneliti perlu mengevaluasi persepsi siswa tentang penggunaan Pengucapan Bahasa Inggris dalam memahami pengucapan akhiran-
\end{abstract}

Lectura: JurnalPendidikan, Vol.12 No. 2, Agustus 2021 
s. Tujuan dari penelitian ini adalah untuk mengetahui persepsi siswa tentang penggunaan English Pronunciation dalam memahami ending -s. Metode yang digunakan dalam penelitian ini adalah kualitatif, dan dijelaskan secara deskriptif. Mahasiswa semester tiga STBA Persada Bunda yang menggunakan aplikasi Pengucapan Bahasa Inggris ini dalam memahami akhiran merupakan populasi sekaligus sampel penelitian ini. Ada 10 mahasiswa STBA Persada Bunda tahun ajaran 2018/2019 yang terlibat dalam penelitian ini. Untuk mengumpulkan data, semua siswa diminta sebelum menggunakan Pengucapan Bahasa Inggris dalam memahami akhiran - s dari aplikasi online dan offline. Kemudian, peneliti membagikan enam pertanyaan terkait persepsi siswa dalam menggunakan Pengucapan Bahasa Inggris dalam memahami akhiran $-s$ dengan menggunakan wawancara dengan model semi terstruktur. Hasil penelitian menunjukkan bahwa, sebagian besar siswa kelas tiga didorong untuk menggunakan Pengucapan Bahasa Inggris dalam memahami akhiran dalam memperoleh pengetahuan dan kegembiraan saat proses belajar tentang suara bersuara, suara tak bersuara, dan suara mendesis. Kesimpulannya, penelitian tentang persepsi siswa adalah respon positif dengan menggunakan English Pronunciation dari pada pengucapan kata berakhiran s atau ending $-s$.

Kata kunci: Persepsi mahasiswa, English Pronunciation aplikasi android, pengucapan akhiran $-s$

\section{INTRODUCTION}

In learning English, the educators were utilizing the most recent data, technique, and application to help the necessities in the classroom. Because of those issues, the advancement of innovation android based becomes the simple thing to discover everything to help the learning in twenty first century or notable as millennial period. Execution of media of learning as android based that is essential for ICT or Information, Communication, and technology) centres on the students, local area in the homeroom, creation and the conveying the appropriate material (Goh: 2009).

It should have been created since the capacity in communicating in English as unknown dialect in Indonesia become significant point and for everybody should allow the opportunity to learn English (Lauder: 2008). Additionally, if the students become familiar with the dynamic expertise as talking ability, particularly in articulation, it will require the information on phonetic and phonology. The information on phonetic and phonology identified with the oral capability (Chen and Gowsami (2010). As such, the capacity of oral capability can be seen from the capacity in articulating great of each word in English. Even though, the differentiation of sound variety of word happens on account of the distinctive social foundation (Winarno and Bandjarjani: 2008; Siahpoosh: 2008).

In accordance with the issue while instructing learning measure, the analysts recognized the articulation issue in committing error in pronouncing ending $-\mathrm{s}$ by utilizing English Way to express android application. To see the view of utilizing English Way to express android application, the analysts needed to lead an exploration particularly in pronouncing ending $-\mathrm{s}$ by talking a few inquiries to acquire some data of understudies' insight. There are a few sources expressed that 
execution of media of learning by application in it as games will be intrigued to apply, simple to remember, and simple to expound the cerebrum and mental of the students by carrying out the appropriate application (Rofiyarti and Sari: 2017; Kurniawan; 2008). Be that as it may, the specialists needed to restrict about the understudies' view of the application android situated in articulation named 'Students' Perception of English Pronunciation Application in Pronouncing Ending -s."

In view of the definition of the exploration over, the objective of the research was to find out the students' perception of using English Pronunciation application in understanding pronunciation ending $-s$ ?. Then, the needs of the research in students " perception of using English Pronunciation application in understanding pronunciation ending $-s$, it will be valuable for university learners in using android in positive way to improve their English competency and also give benefit to the lecturers in teaching other courses in English Department as an effective media of learning while teaching-learning process.

In this related theories to support this research, the researchers tried to explain the theory of the benefit of technology or the application of android based, teaching pronouncing ending $-\mathrm{s}$. The researchers used the pronunciation theory by Dale and Poms to elaborate the findings and discussion of this research.

\section{The Benefit of Technology}

Information and Communication Technology or called as ICT, that told about the technology which is having the application to share data and correspondence from individual or association through time and spatial (Dettori and Persico: 2011).
In utilizing technology, the client should focus on these five standards. To begin with, the technology should offer the chance to peruse, compose and examine; second the innovation should make the students more clarity of mind; third the technology should give the time; fourth the technology should give the students made mistake and self-rightness; and fifth the technology should allow the opportunities to investigate their elocution (Erben, Boycott, and Castaneda: 2009). To abstain from deceiving while at the same time utilizing technology, the client should diagram a few focuses that become consideration prior to applying technology in the instructing learning measure. Initially, it is better for the educators to check the application to ensure everything is reasonable prior to beginning the class. Also, the instructor should make the guideline while utilizing this technology, similar to the prohibited words is restricted in that school (Mahmudah: 2015).

\section{Pronunciation Ending $-S$}

The word 'pronunciation' refers to English phonology terms as one of it is International Phonetic Association (IPA) transcription. This International Phonetic Association (IPA) transcription is required and vital on the grounds that it is a device to use to translate the letters in order as a rule. [Ogden: 2009; Gut: 2009). Agreement with the past assertions, the word 'elocution' characterizes the way or rules in spellings on vocal sound and consonant sounds (Alan: 2014).

With the exception of clarifying on the record, the specialists attempted to lay out a concise clarification on the elocution finishing $-\mathrm{s}$. The issue of articulating $-\mathrm{s}$ consistently existed in way to express plurals, third-individual action words, and withdrawals existing in the closures of words. Concurring Dale and Poms (2005) 
expressed that there are the principles to stay away from the issues in articulating plurals, third-individual action words, and compressions. It tends to be viewed as follows. In the first place, the completion $\mathrm{s}$ framing the plural, the third-individual, and withdrawal will consistently seem like/s/when the last strong of the base structure is voiceless sound. Second, the closure $-\mathrm{s}$ framing the plural, the thirdindividual, and constriction will consistently seem like/z/when the last solid of the base structure is voiced sound. Third, the closure $-\mathrm{s}$ shaping the plural, the thirdindividual, and compression will consistently seem like/rz/when the last strong of the base structure is sibilant sounds. These three guidelines have managed the information on phonological terms like voiceless, voiced, and sibilant sound. To find out about these terms in phonology, the students ought to learn first pretty much all sounds.

In this part, the researchers took these related findings that used technology in learning English. The related findings that can accentuate this examination can be viewed as follows.

1. The first related finding was going to realize the best approach to foster an application android based. It was created to help the articulation in advanced education and to carry out the application (Anggraini, Novianti, and Bardadi: 2018). The outcome showed that all respondents had the option to comprehend and apply the application well. The similitude of this past examination to this exploration was about the articulation identified with application android based. The distinction of this past examination to this exploration was not in planning an application but rather in carrying out the application existed on the media of learning of android based.

2. The second related finding was tied in with showing English particularly in elocution. The outcome showed that the instructors English as Second language accepted that the elocution capacity should instruct incorporated to different abilities of English (Shah, Othman, and Senom: 2017). The other outcome showed that the educators accepted that zeroed in on the articulation matter distinctive to the educational plan dispersed in school. The closeness of this past examination to this exploration zeroed in on the elocution and utilized an application. The distinction of this past exploration to this examination was the application utilized.

3. The last related finding was about the Duolingo application applied in articulation (Mahmudah: 2015). The outcome showed that this application was viable to improve the students' capacity in articulation in fundamental level. The comparability of this past examination to this exploration zeroed in on the elocution that was utilized application existed in android. The distinction of this past exploration to this examination was not mattering the Duolingo application as an activity research anyway this exploration utilized Elocution application to improve the students' capacity in articulation on the application existed on the media of learning of android based.

\section{METHOD}

This study was a descriptive research, which aimed to evaluate the students' perception of the use of android application in ending -s. This research was held at STBA Persada Bunda located at Diponegoro street 42 Pekanbaru, Riau. The respondents of this research were all number of students that were the second year students of English Letter Department in 2018/2019 about 10 students. The researchers only focused on students' perception of using English 
Pronunciation application in understanding pronunciation ending $-\mathrm{s}$.

In addition to, the research instruments of this research in order to collect the data were six questions of semi-structured of interview. It aimed to gain the students' perception of understanding pronunciation of ending -s by using English Pronunciation of android application. The questions would be like in the following explanation. First, the question was about effective or not effective of using English Pronunciation of android application to gain information of pronunciation of ending -s. Second, the question was about the positive effect of using English Pronunciation of android application understanding pronunciation of ending -s. Third, the question was about the negative point of using English Pronunciation of android application in understanding pronunciation of ending -s. Fourth, the question was about the existence English Pronunciation application of voiceless sounds contributes to the pronunciation ending $-\mathrm{s}$ especially for sound /s/ or not. Fifth, the question was about the existence English Pronunciation application of voiced sounds contributes to the pronunciation ending $-\mathrm{s}$ especially for sound /z/ or not. Sixth, the question was about the existence English Pronunciation application of sibilant sounds contributes to the pronunciation ending $-\mathrm{s}$ especially for sound /z/ or not. All of points about ending $-\mathrm{s}$ have been analyse and known the scoring of students's understanding of using English Pronunciation of android application of ending $-\mathrm{s}$.

In collecting the data of this research, the researcher collected data by using interview to gain the information relate to students' perception of the use of android application in understanding pronunciation of ending -s. The type of interview used was semi-structured interview. This type of interview was suitable to this aim of research since the interview not asking directly only to the questions given, but also the reason needed related of each question to support the question itself. The procedures would be like this following explanation. First, the researcher asked the student one by one to conduct an interview that had arranged before based on the need of this aim of the research about students' perception in of using English Pronunciation of Android application of ending -s. Second, the researchers prepared about six questions for the interview. The questions would be like:

a. Do you think English Pronunciation of android application is an effective technique to gain the information of pronunciation of ending $-s$ ?

$b$. What are the positive effect of using android application in pronunciation of ending $-s$ ?

c. What are the negative point of using android application in pronunciation of ending $-s$ ?

d. Do you think that English Pronunciation application of voiceless sounds contribute to the pronunciation ending $-s$ especially for sound /s/ or not?

e. Do you think that English Pronunciation application of voiced sounds contribute to the pronunciation ending $-s$ especially for sound / $z$ / or not?

f. Do you think that English Pronunciation application of sibilant sounds contribute to the pronunciation ending $-s$ especially for sound /Iz/ or not?

For the answer, the researchers asked the students perception to answer prepared other optional choices, if the students could not describe about their perceptions. The optional choices would deliver after the students answered the question about students' perception. For example the question about Do you think 
English Pronunciation of android application is an effective technique to gain the information of pronunciation of ending $-s$ ?, the optional choices would be like effective technique and not effective technique. To see the other optional choices, the researchers explained it in the Finding and Discussion below.

\section{The Data Analysis Technique}

In analysing the data of this research, after the students responded all the questions given about the students' perception of the use of English Pronunciation of android application in understanding pronunciation of ending -s, the researchers counted the response by the students and changed it into percentage of each question.

After calculating the students ${ }^{6}$ responses, the researchers tried to draw the result of this research into diagram and gave some explanation relating to the diagram to explain the students ${ }^{6}$ perception of using English Pronunciation application in understanding pronunciation of ending s.

\section{FINDINGS AND DISCUSSION}

In this part, the researchers wanted to share some discussions of the questions distributed to the students about the students' perception of the use of English Pronunciation of android application in pronunciation of ending -s. There were 10 students attending sociolinguistics subject in Foreign Language College (STBA) Persada Bunda participated to give response the questions in this research.

\section{Results of the semi-structured interview}

1. Do you think English Pronunciation of android application is an effective technique to gain the information of pronunciation of ending $-s$ ?
The related graph of the question English Pronunciation of android application as an Effective application of ending $-\mathrm{s}$ were responded as:

1. Effective technique 90 percentage

2. Not Effective technique 10 percentage From the graph below, there were 9 students out of 10 that gave positive response to this question. Only 1 student thought that English Pronunciation of android application was not an effective technique. The percentage showed that the most dominant point about 90 percentage was in positive response, -effective.

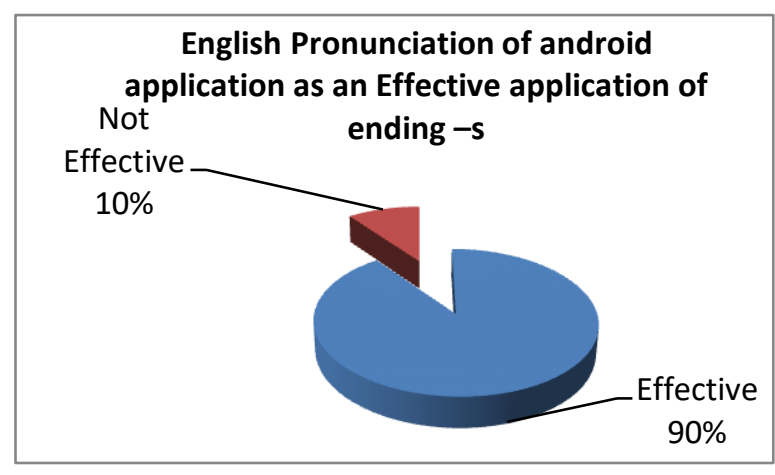

Figure 1. The portion of Students' Perception about using English Pronunciation of android application

In other hands, only 10 percentages was in negative response, not effective. It could be stated that the students perception of this question that was it was effective to the students in using English Pronunciation of android application in understanding pronunciation of ending -s. However, only one student did not give the positive response, as not effective because of the reason stated below.

Statement: -I think that it was not an effective, because I don't use android as my mobile phone, I use i-Phone, that does not support the application. 
From this response, the condition of student mobile phone became a problem in effectiveness of using English Pronunciation in android application. Even it was only one student, the use application of English Pronunciation could be said as non-effective way, even the student could use another application of English Pronunciation in i-Phone. It was still not the same application matter.

2. What are the positive effect of using android application in pronunciation of ending $-s$ ?

The responses of the students of the question -the positive effect of the use of English Pronunciation application in pronunciation of ending $-\mathrm{s}$ were responded as:

1. Joy able 10 percentages

2. Not boring 10 percentages

3. Stimulated 40 percentages

4. Clear Example 20 percentages

5. Understandable 20 percentages

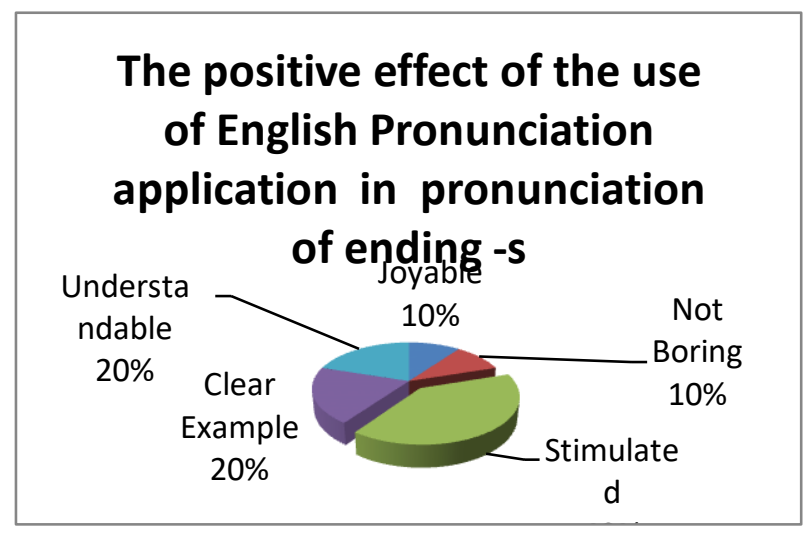

Figure 2. The portion of Students' Perception about the positive effect of using android application in pronunciation of ending $-S$

From the Figure 2 above, it could be seen that there were 5 categories of responses. They are fun, not boring, motivating, clear conversation, and understandable. The percentage of the students' perception of the question -the positive effect of the use of English Pronunciation of this android application of pronunciation of ending -s showed that the most dominant point about 40 percentage responded-stimulated. There were 2 (two) responses as -clear example and -understandable that were responded in the same range of percentage, about 20 percentage. Then, the two last responses of this question were responded as -joy able and -not boring were the same percentage, about 10 percentage. It could be stated that the students perception of this question about the positive effect of the use of English Pronunciation of android application were stimulated, clear example, understandable, joy able and not boring in order of the percentage range.

From the discussion above, only some of students understand the material of ending $-\mathrm{s}$ by using android application of English Pronunciation. It happened because the material of ending $-\mathrm{s}$ not mention directly in android application of English Pronunciation. The material in English Pronunciation is about the voice sound of native when the students typed some words of ending $-\mathrm{s}$, and then listened it carefully. Also, the students got the information from the material about voice sound, voiceless sound and sibilant sound of the pronunciation of ending $-\mathrm{s}$ indicating sound /s/, sound /z/, or /Iz/. The specific questions about ending $-\mathrm{s}$ sound /s/, sound /z/, and /Iz/ can be seen in the question number 4,5 , and 6 below.

3. What are the negative point of using android application in pronunciation of ending $-s$ ?

From this part of question, the result of the responses of the negative effect of the use of English Pronunciation application in pronunciation of ending -s can be seen in the following paragraph. 
The responses of the students of the question -the negative effect of using English Pronunciation application in pronunciation of ending -s were responded as:

1. Only selected example 60 percentage

2. Not easy to access 10 percentage

3 . Not easy to apply 10 percentage

4. Not creative enough 20 percentage

It could be seen that there were 4 categories of responses. They are only selected example, not easy to access, not easy to apply, and not creative enough. The response as not creative enough was responded about 20 percentage.

The percentage of the students perception of the question -the negative effect of the use of English Pronunciation of android application of pronunciation of ending -s showed that the most dominant point was about 60 percentage responded -only selected example. In short, the application of English Pronunciation should be mixed with other example from the lecturer to make them understandfully of ending $-\mathrm{s}$.

The response as not creative enough was responded about 20 percentage. It happened because there is only a few emoticon, or picture to attract the students' interest as creative application. The application of English Pronunciation serves some pictures about the voice sound, the voiceless sound, and the sibilant sound as material of pronunciation of ending $-\mathrm{s}$.

Then the last same percentage -not easy to access and not clear sound- that was responded about 10 percentage. In conclusion, the response can be concluded that English Pronunciation has only negative point in 10 percentage in two categories. Not easy to access, it is about English Pronunciation online and needs internet connection. Not clear sound, it about the sound of native in English Pronunciation either online or offline application. To solve the problem, the students should hear the voice of native most of the time.

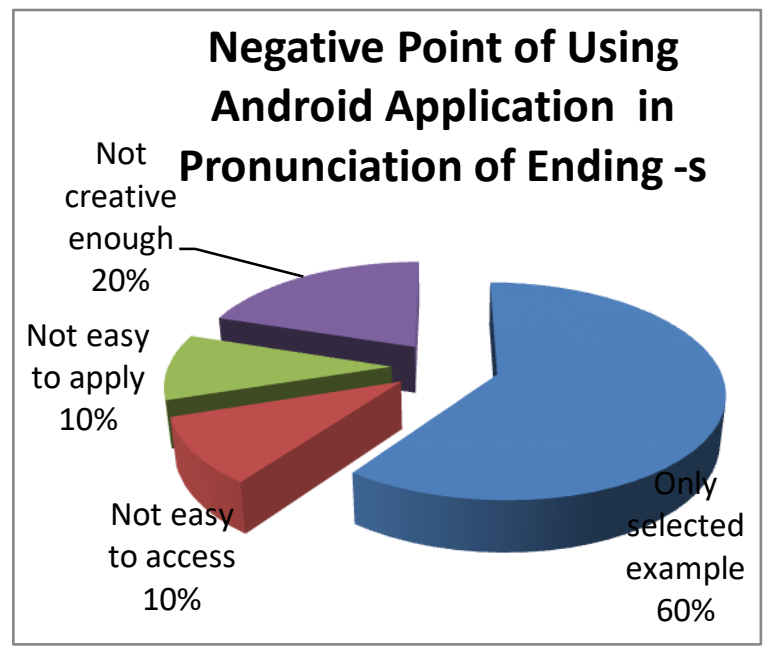

Diagram 3. Percentage of students' perception about the negative point of using android application in pronunciation of ending $-s$

From the Diagram 3, it could be seen that there were 4 responses. They were only selected example 60 percentage, not easy to access 10 percentage, not easy to apply 10 percentage, and not creative enough 20 percentage.

4. Do you think that English Pronunciation application of voiceless sound contribute to the pronunciation ending $-s$ especially for sound /s/ or not?

The students' perception of English Pronunciation application of voiceless sound contribute to the pronunciation ending $-s$ especially for sound /s/ or not were responded as:

1. Yes, sure. It shows the voiceless sounds contributing of ending $-\mathrm{s}$ sound $/ \mathrm{s} / 80$ percentage.

2. No, more confusing 20 percentage

There were 8 students out of 10 that gave positive response, as -yes, sure. It shows the voiceless sounds contributing of ending $-\mathrm{s}$ sound /s/. There were 2 students thought that English Pronunciation of 
android application was negative response, -no, more confusing, about 20 percentage.

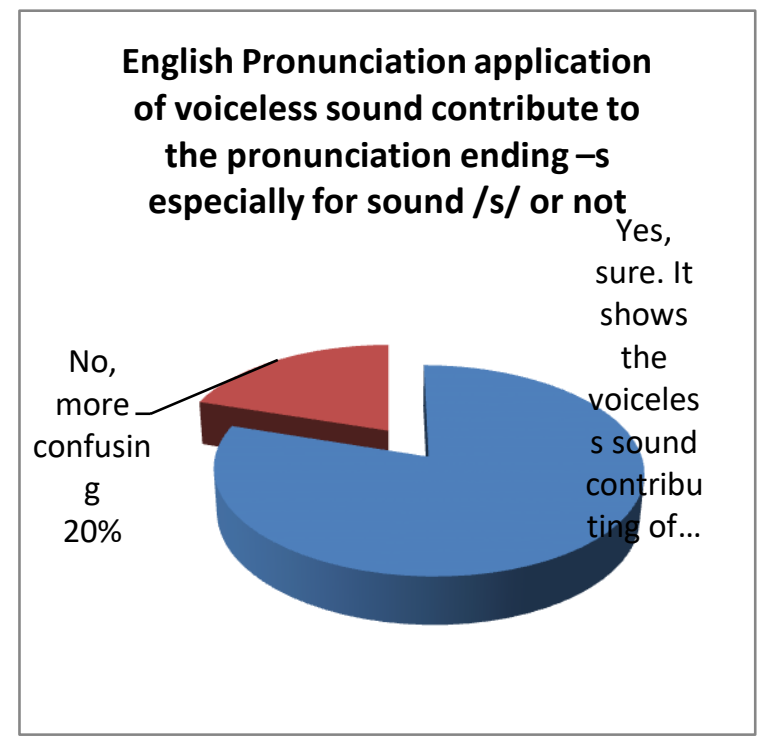

Diagram 4. Percentage of students' perception about English Pronunciation application of voiceless sound contribute to the pronunciation ending $-S$ especially for sound /s/ or not

From the diagram above, the percentage showed that the most dominant point about 80 percentage was in positive response, -yes, sure. It shows the voiceless sounds contributing of ending $-\mathrm{s}$ sound /s/. However, only 20 percentage was in negative response, -no, more confusing. It could be stated that the students perception of this question about the English Pronunciation application of voiceless sound contribute to the pronunciation ending $-\mathrm{s}$ especially for sound $/ \mathrm{s} /$ or not.

5. Do you think that English Pronunciation application of voiced sound contribute to the pronunciation ending $-s$ especially for sound $/ z /$ or not?

The students' perception of English Pronunciation application of voiced sound contributes to the pronunciation ending $-s$ especially for sound $/ z /$ or not was responded as:
1. Yes, sure. It shows the voiced sounds contributing of ending $-\mathrm{s}$ sound /z/ 80 percentage

2. No, more confusing 20 percentage There were 8 students out of 10 that gave positive response, as -yes, sure. It shows the voiced sounds contributing of ending - s sound /z/. There were 2 students thought that English Pronunciation of android application was negative response, -no, more confusing, about 20 percentage.

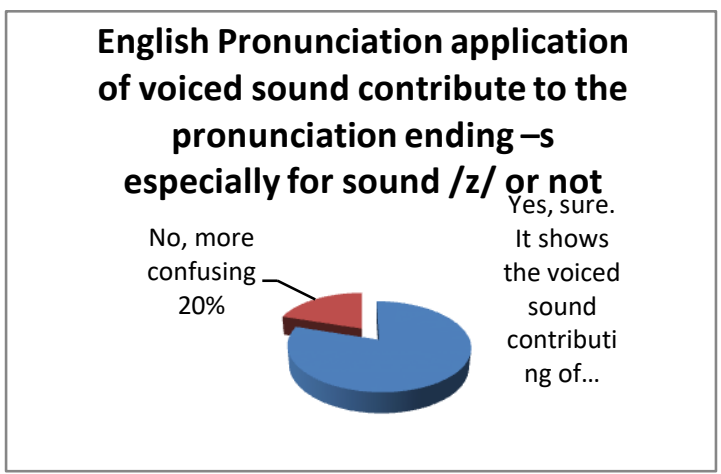

Diagram 5. Percentage of students' perception about English Pronunciation application of voiced sound contribute to the pronunciation ending $-S$ especially for sound $/ z /$ or not

From the diagram above, the percentage is the same as to the previous question. It showed that the most dominant point about 80 percentages was in positive response, -yes, sure. It shows the voiced sounds contributing of ending $-\mathrm{s}$ sound /z/. However, only 20 percentage was in negative response, -no, more confusing. It could be stated that the students perception of this question about the English Pronunciation application of voiced sound contribute to the pronunciation ending $-\mathrm{s}$ especially for sound /z/.

6. Do you think that English Pronunciation application of sibilant sound contribute to the pronunciation ending $-s$ especially for sound / $\mathrm{Iz} /$ or not? 
The students' perception of English Pronunciation application of sibilant sound contributes to the pronunciation ending $-s$ especially for sound / $\mathrm{Iz} /$ or not was responded as:

1. Yes, sure. It shows the sibilant sounds contributing of ending - s sound /Iz/ 100 percentage

2. No, more confusing 0 percentage

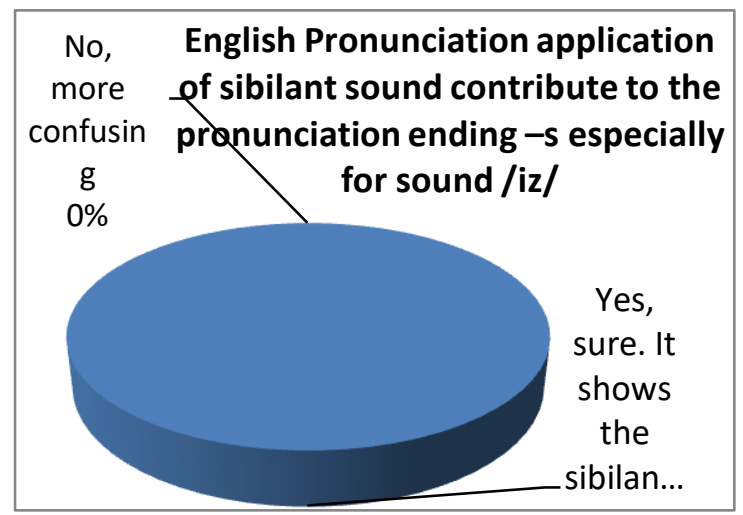

Diagram 6. Percentage of students' perception about English Pronunciation application of sibilant sound contribute to the pronunciation ending $-s$ especially for sound / Iz/ or not

All of students of 10 students gave positive response, as -yes, sure. It shows the sibilant sounds contributing of ending s sound /Iz/. There was no students thought that English Pronunciation of android application was negative response, -no, more confusing, about 0 percentage.

From the diagram 6, all of students' response were 100 percentage was in positive response, -yes, sure. It shows the sibilant sounds contributing of ending $-\mathrm{s}$ sound /Iz/. However, zero percentage was in negative response, -no, more confusing. It could be stated that the students perception of this question about the English Pronunciation application of sibilant sound contribute to the pronunciation ending $-\mathrm{S}$ especially for sound /Iz/.

\section{CONCLUSION}

Based on findings and discussions in this study, it could be concluded that the students' perception of the use of English Pronunciation in understanding ending $-\mathrm{s}$ are in positive response. The explanation of the results and discussions are shown by these points as follows.

The students' perception of the use of English Pronunciation in understanding ending $-\mathrm{s}$ are divided into six questions of semi-structured interview. The questions would be like in the following explanation. First, the question was about effective or not effective of using English Pronunciation of android application to gain information of pronunciation of ending -s. Second, the question was about the positive effect of using English Pronunciation of android application understanding pronunciation of ending -s. Third, the question was about the negative point of using English Pronunciation of android application in understanding pronunciation of ending -s. Fourth, the question is about the existence English Pronunciation application of voiceless sounds contributes to the pronunciation ending $-\mathrm{s}$ especially for sound /s/ or not. Fifth, the question is about the existence English Pronunciation application of voiced sounds contributes to the pronunciation ending $-\mathrm{s}$ especially for sound /z/ or not. Sixth, the question was about the existence English Pronunciation application of sibilant sounds contributes to the pronunciation ending -s especially for sound /z/ or not.

1. From the first question of effective or not effective of using English Pronunciation of android application to gain information of pronunciation of ending $-s$, the students' perceptions 
mostly gave positive response as the effective technique.

2. From the second question of the positive effect of using English Pronunciation of android application understanding pronunciation of ending $\mathrm{s}$, the students" perception gave in different responses, as can be divided into stimulated, clear example, understandable, joy able and not boring

3. From the third question of the negative point of using English Pronunciation of android application understanding pronunciation of ending -s, the students ${ }^{6}$ perception gave in different responses, as can be divided into only selected examples, Not creative enough, not easy to access, and not easy to apply.

4. From the fourth question of the students perception of the existence English Pronunciation application of voiceless sounds contribute to the pronunciation ending - s especially for sound /s/ or not. It showed that mostly students gave the positive response as -yes response of 80 percentages.

5. From the fifth question of the students' perception of the existence English Pronunciation application of voiced sounds contribute to the pronunciation ending $-\mathrm{s}$ especially for sound $/ \mathrm{z} /$ or not. It showed that mostly students gave the positive respond as -yes response of 80 percentage.

6. From the fourth question of the students' perception of the existence English Pronunciation application of sibilant sounds contribute to the pronunciation ending $-\mathrm{s}$ especially for sound /Iz/ or not. It showed that all students gave the positive response as -yes response of 100 percentage.

7. In this research, there was no research using this English Pronunciation application. However, most research using android application was effective enough by some weaknesses inside application. These were several researches in line to this research. They were Anggraini, Novianti, and Bardadi: 2018 about designing the pronunciation application, Shah, Othman, and Senom: 2017 about the pronunciation matter different to the curriculum distributed in school, Mahmudah: 2015 about the Duolingo application applied in pronunciation.

Then, for the suggestions of this research, it can be seen in the following points. First, the English Pronunciation application should pay attention to ending $-s$, especially the example of voiceless sounds, voiced sound and sibilant sounds. To ease the students' understanding about pronunciation of ending $-\mathrm{s}$. Second, in addition to future researchers, the researchers' needs to develop more questions based on other topics and applications, other type of interview, except semi-structured interview.

\section{REFERENCES}

Alan, Cruttenden. 2014. Gimson's Pronunciation of English. Eighth Edition. London and New York: Routledge.

Anggraini, Hesti Wahyuni, H. Novianti, A. Bardadi. 2018. Pengembangan Bahan Ajar Berbasis Android untuk Meningkatkan Kemampuan Pengucapan pada Mahasiswa. CESS (Journal of Computer Engineering System and Science), Volume 3 Nomor 1. Retrieved from http://jurnal.unimed.ac.id/2012/index. $\mathrm{php/cess/article/download/7854/7747.}$

Chen, Hsuan-Yu \& Jaya S. Gowsami. 2010. "The Impact of Phonetic and Phonological Instruction on the Oral Proficiency of Spanish-speaking ESL Learners", The Asian EFL Journal, 
Special Edition, The 1st Asian Cebu Conference, Time Taylor Press page 111-123. Ed. P. Robertson dan R. Nunn.

Dale, Paulete and L, Poms. English Pronunciation Made Simple. New York: Pearson Education, 2005.

Dettori, Giulana and D. Persico. 2011. Fostering Self-Regulated Learning through ICT. Harshey and New York: Information Science Reference. Harshey and New York: Information Science Reference

Erben, Tony, R. Ban, and M. Castaneda. 2009. Teaching English Language Learners through Technology. New York: Routledge

Fathira, Vina. 2017. Analysis of EFL Students' Ability in Reading Vocabulary of Synonyms and Antonyms. Lectura: Jurnal Pendidikan, Vol 8 No.1 (2017). Retrieved from https://ejurnal.unilak.ac.id/index.php/ lectura/article/view/426/309.

Goh, Tiong T. 2009. Multiplatform ELearning Systems and Technologies: Mobile Devices for Ubiquitous ICTBased Education. Harshey and New York: Information Science Reference

Gut, Ulrike. 2009. Introduction to English Phonetics and Phonology. Frankfurt: Peter Lang, I nternationa ler Verlag der Wissenschaften.

Kemmis, S., and McTaggart, R. 2014. The Action Research Planner. Revised Edition. Geelong: Deakin University Press.

Kurniawan, Yudha. 2008. Creative Games for Kids. Jakarta: Wahyu Media.

Lauder, Allan. 2008. "The Status and Function of English in Indonesia: A Review of Key Factors", Jurnal Makara, Sosial Humaniora, Vol. 12,
No. 1, Juli 2008: 9-20. Depok: Universitas Indonesia.

Mahmudah, Laila. 2015. An analysis of Pronunciation Exercises in Duolingo Application and Its Contribution as English Learning Media. Unpublished. Retrieved from http://eprints.walisongo.ac.id/5059/1/ 113411023.pdf

Ogden, Richard. 2009. An Introduction to English Phonetics. Edinburgh: Edinburgh University Press.

Rofiyarti, Fitri, dan A. Y. Sari. 2017. "Tik untuk Aud: Penggunaan Platform "Kahoot!" dalam Menumbuhkan Jiwa Kompetitif dan Kolaboratif Anak", PEDAGOGI: Jurnal Anak Usia Dini dan Pendidikan Anak Usia Dini, Volume 3 Nomor 3b Desember 2017, pp 164-172.

Shah, Shanina Sharatol Ahmad, J. Othman, and F. Senom. 2017. The Pronunciation Component in ESL Lessons: Teachers' Beliefs and Practices. Indonesian Journal of Applied Linguistics, Vol. 6 No. 2, January 2017, pp. 193-203. Retrieved from http://ejournal.upi.edu/index.php/IJA L/article/view/4844.

Siahpoosh, Hossein. 2008. "Pronunciation in EFL Classes and the Personality Factors in Learning Pronunciation", TEFLIN: 6th Asia TEFL International Conference, 1-3 Agustus 2008. Bali, Indonesia.

Winarno dan W. Bandjarjani. 2008. "Manipulating Local Tongue Twisters As An Alternative To Improve English Learners' Pronunciation", TEFLIN: 6th Asia TEFL International Conference, 1-3 Agustus 2008. Bali, Indonesia. 